\title{
Key Activities of Menu Management and Analysis Performed by SME Restaurants in Malaysia
}

Hao Bin Jack Lai, Muhammad Rezza Zainal Abidin, Muhamad Zulfikri Hasni, Muhammad Shahrim Ab Karim, and Farah Adibah Che Ishak

To Link this Article: http://dx.doi.org/10.6007/IJARBSS/v11-i4/9184

DOI:10.6007/IJARBSS/v11-i4/9184

Received: 14 February 2021, Revised: 17 March 2021, Accepted: 01 April 2021

Published Online: 19 April 2021

In-Text Citation: (Lai et al., 2021)

To Cite this Article: Lai, H. B. J., Abidin, M. R. Z., Hasni, M. Z., Karim, M. S. A., \& Ishak, F. A. C. (2021). Key Activities of Menu Management and Analysis Performed by SME Restaurants in Malaysia. International Journal of Academic Research in Business and Social Sciences, 11(4), 339-361.

Copyright: (c) 2021 The Author(s)

Published by Human Resource Management Academic Research Society (www.hrmars.com)

This article is published under the Creative Commons Attribution (CC BY 4.0) license. Anyone may reproduce, distribute, translate and create derivative works of this article (for both commercial and non-commercial purposes), subject to full attribution to the original publication and authors. The full terms of this license may be seen at: http://creativecommons.org/licences/by/4.0/legalcode

Vol. 11, No. 4, 2021, Pg. 339 - 361

Full Terms \& Conditions of access and use can be found at http://hrmars.com/index.php/pages/detail/publication-ethics 


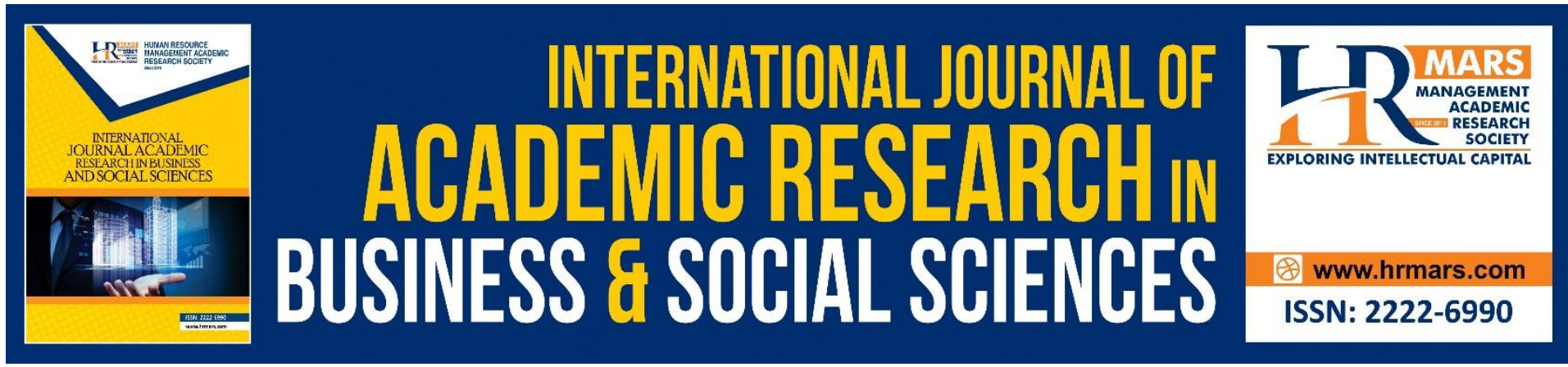

\title{
Key Activities of Menu Management and Analysis Performed by SME Restaurants in Malaysia
}

\author{
Hao Bin Jack Lai, Muhammad Rezza Zainal Abidin, Muhamad \\ Zulfikri Hasni, Muhammad Shahrim Ab Karim, and Farah \\ Adibah Che Ishak \\ Department of Food Service and Management, Faculty of Food Science and Technology, \\ Universiti Putra Malaysia, Selangor, Malaysia \\ Email: gs52634@student.upm.edu.my, gs52267@student.upm.edu.my, \\ gs53324@student.upm.edu.my, shahrim@upm.edu.my, farahadibah@upm.edu.my
}

\begin{abstract}
Menu management and analysis is commonly performed by food and beverage establishments to develop, monitor, and modify menu items. However, previous studies seldom associate and study menu management functions concurrently. These functions include but are not limited to menu planning, menu design, menu pricing, menu operation and menu analysis. This exploratory study explored the measures taken by SME restaurant decision-makers in managing their menus. Participants put forward that the measures taken to manage their menus within their establishments are limited by their capabilities and conditions. Participants identified key activities of menu management and analysis as menu development and modification, menu positioning, menu operational efficiency as well as menu pricing and cost control. At the same time, findings showed that key considerations should be given to employees, customers, restaurant resources and the business environment when making decisions pertaining to menu management and analysis. Practitioners in Kuala Lumpur commonly operate their restaurants without specific menu management method, but manages their respective menus depending on the business environment, resources, and capabilities. Furthermore, practitioners seek operational examples and take pricing references from other successful competitors. This study presents that a balance of both quantitative analytics and qualitative reasoning are key to achieving menu profitability.
\end{abstract}

\section{Introduction}

In a restaurant, the menu is an essential document to communicate food and beverage offerings whereby if properly designed and managed, it can position and market highly profitable items for the restaurant (Antun \& Gustafson, 2005). According to Kincaid \& Corsun (2003), menu management should ensure that value and satisfaction are maintained while achieving profits. While there are ample of methods that suggest the best ways to manage and analyse a menu, existing literature has mostly discussed about methods developed based on theory and seldom from a practical perspective (Lai, Karim, Krauss, \& Ishak, 2019). Existing 
literature regarding menu management and analysis for restaurants are very theoretical and quantitative driven, developed to achieve the financial goals of a restaurant (Ozdemir \& Caliskan, 2014). That said, practitioners seldom apply completely what is suggested in the research literature as certain implications may seem theoretically feasible but would be impractical to be implemented (Raab \& Zemke, 2016). This preliminary study hypothesizes that practitioners do what they do because it is what makes sense to them, considering their current working conditions and business environments. If existing methods on menu management and analysis are only applied partially, sophisticated methods would never be considered by independent restaurant businesses. Hence, this paper sheds light on key practical activities on managing menu profitability among SME restaurant establishments in Kuala Lumpur. It is worth exploring and noting what is being done by practitioners considering current theoretical trends and recommendations.

\section{Literature Review}

Menu management and analysis consists of the actions performed to develop, track, and modify the menu of a restaurant consistently. However according to Ozdemir \& Caliskan (2014), existing research in this domain is relatively independent as menu management is a concept that researchers and practitioners seldom recognize. Ozdemir \& Caliskan's (2014) review paper explored prominent studies associated with the domain of menu management that categorized key activities into menu planning, menu pricing, menu designing, menu operating and menu analysis. Although these functions are commonly performed by practitioners, researchers seldom associate and examine these functions concurrently. During the development of a menu, Morrison (1997) suggests considering the costs, profitability, skills of employees and availability of ingredients before finalizing menu items. This concept is similar to Osterwalder \& Pigneur's (2010) business model canvas which borrows from marketing and management theory in considering environmental factors before conforming to a certain strategy. 


\section{Menu Development}

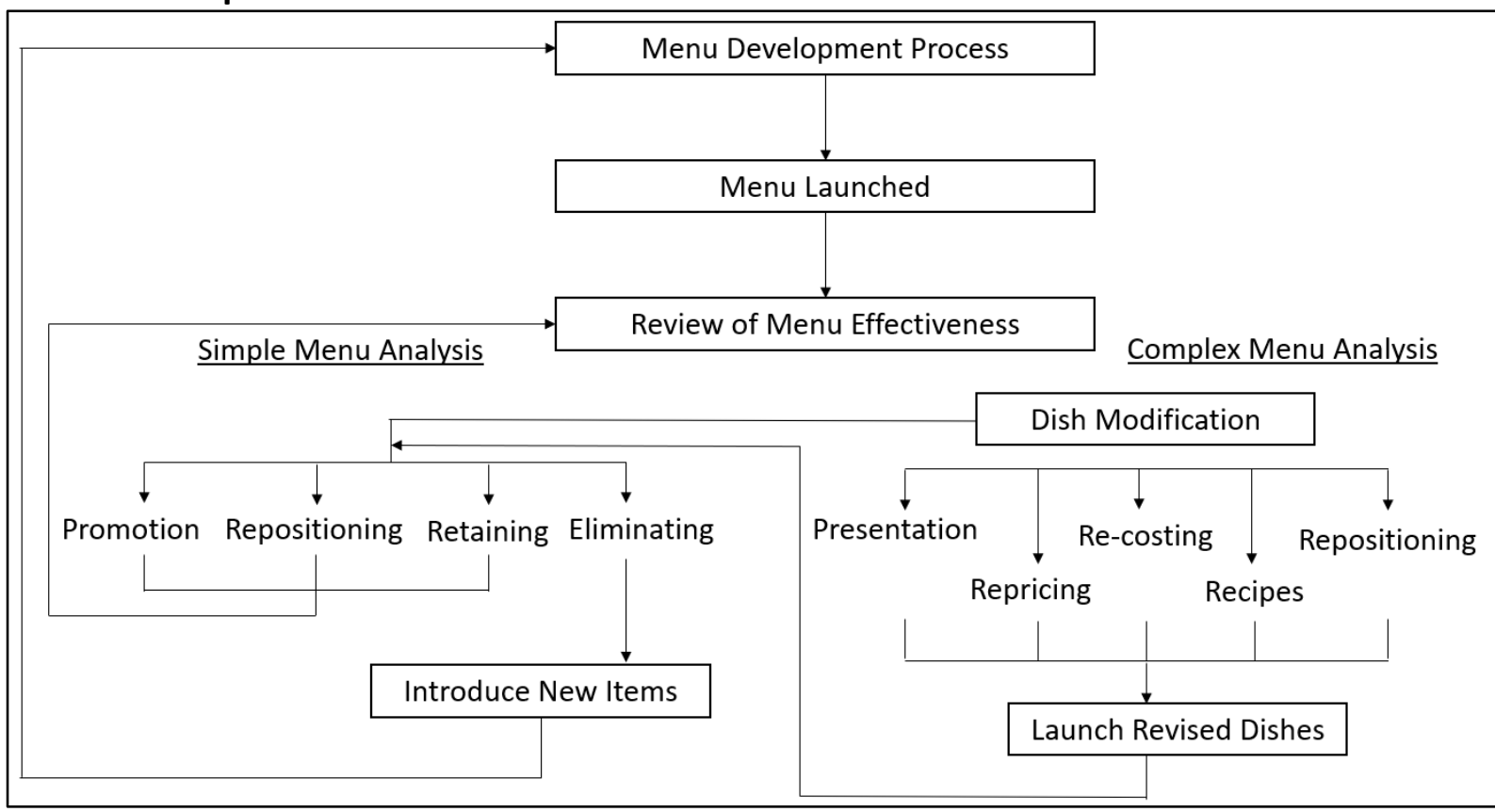

Figure 1 Menu development and analysis (Jones \& Mifli, 2001)

The model depicted in Figure 1 developed by Jones \& Mifli (2001) highlights the key activities performed during menu development and analysis based on chain restaurants in the UK. It is an ongoing process of reiterating menu items to achieve optimum profitability. Once a menu is launched, decision-makers would conduct menu analysis to determine the popularity and profitability of every menu item. If required, underperforming menu items will be either modified or eliminated followed by introducing new menu items. This view is supported by Glanz et al. (2007) as a menu should always receive updates to attract and retain customers. 


\section{Menu Effectiveness}

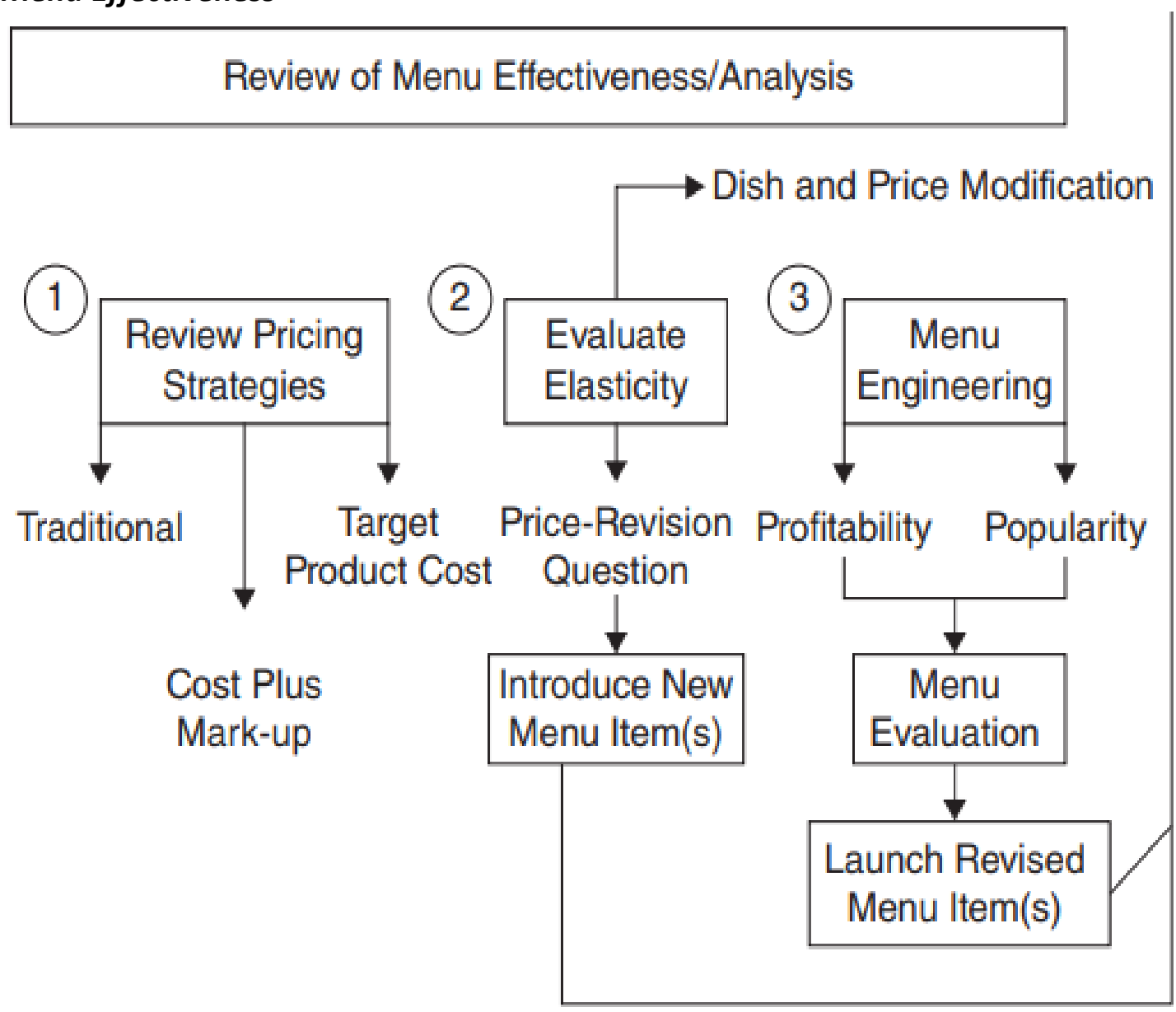

Figure 2 Review of menu effectiveness (Ojugo \& Rymer, 2009)

Figure 2 shows a framework for reviewing menu effectiveness. This review is important to determine the modifications required to improve menu items. As proposed by Ojugo \& Rymer (2009), the activities comprise pricing strategy review, price elasticity, and menu engineering. As agreed by many researchers, the price of the menu heavily influences the purchase decisions of customers. Hence, Iglesias \& Guillén (2004) proposed to consider both the perceived monetary price and non-monetary price when evaluating the performance of menu items. Using this approach, managers can then understand how much more they can charge on different menu items. This is because customers would compare prices of similar menu items from other establishments, resulting in the fluctuation of demand towards the restaurant (Kelly, Kiefer, \& Burdett, 1994). To tackle this, Raab, Mayer, Kim, \& Shoemaker (2009) developed a price sensitivity measurement tool to assess a customer's price sensitivity. Other researchers such as Naipaul \& Parsa (2001) studied the effects of menu price endings towards value and quality perception. Researchers in the field of revenue management have even suggested incorporating demand-based variable pricing where the managers change the prices of their menu items to control demand and optimize margins (Heo, Lee, Mattila, \& Hu, 2013; Kimes, 2010). 


\section{Menu Analysis}

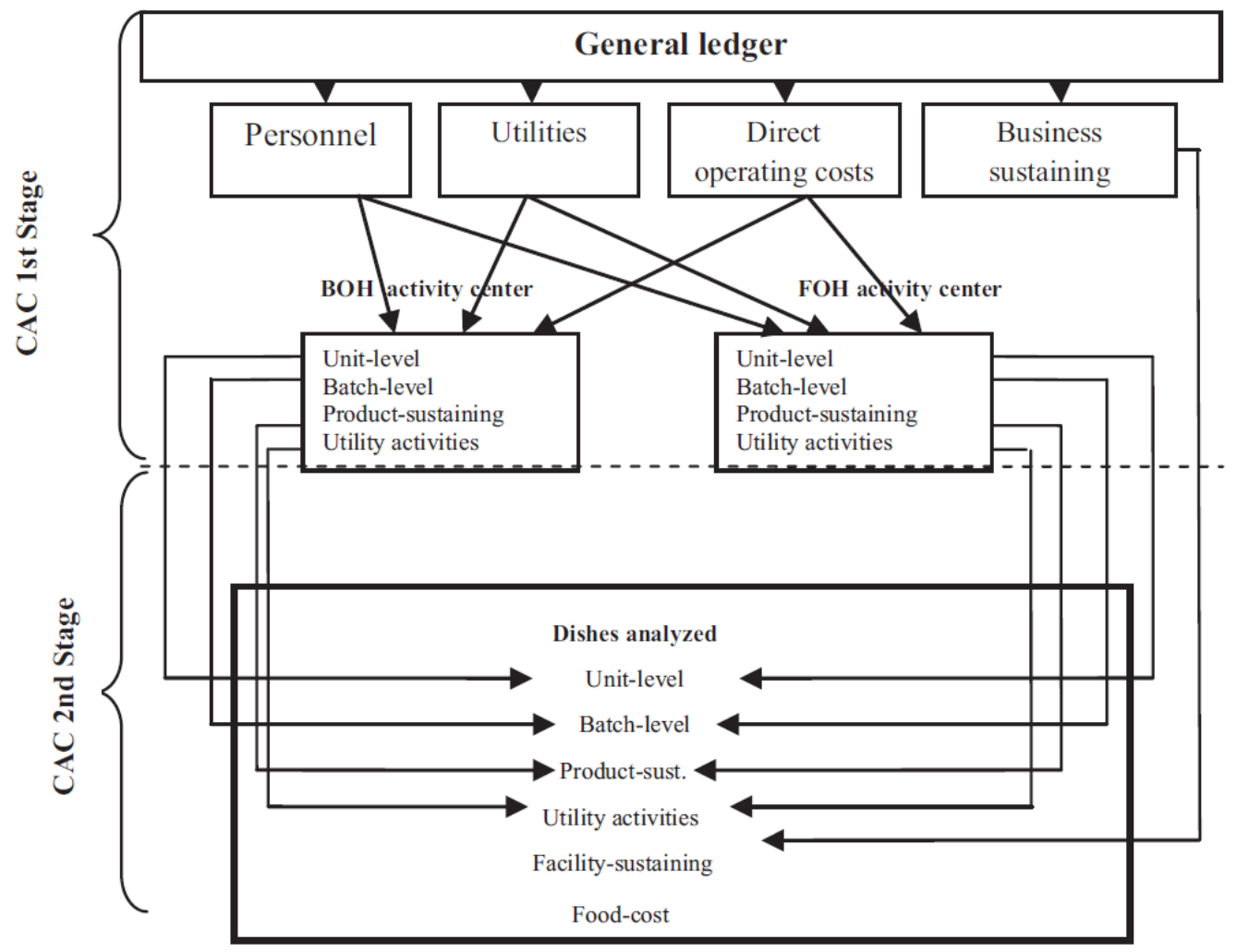

Figure 3 Activity based costing model for restaurants (Raab, 2003)

Research in menu analysis and engineering have evolved significantly from traditional methods towards more sophisticated methods borrowing techniques from the manufacturing industry. Because these methods are more quantitative, they lack the qualitative considerations of labour and customer satisfaction when evaluating menu item performance (Taylor \& Brown, 2007). This results in the lack of rigour as well as missing opportunities when making decisions.

Traditional methods of menu analysis pioneered by Kasavana \& Smith (1982) and Pavesic (1983) rely on matrix based models to account for sales volume, margins and costs of menu items. Thereafter Bayou \& Bennett (1992), Cohen, Mesika, \& Schwartz (1998), Hayes \& Huffman (1985) and LeBruto, Quain, \& Ashley (1995) introduced more variables such as weighted contribution margin and even labour costs to more accurately analyse menu item profitability. Later, researchers began to adapt activity based costing into menu analysis which allocates all fixed and variable costs of the restaurant into menu items (Dalci, Tanis, \& Kosan, 2010; Kaplan \& Anderson, 2007; Raab \& Mayer, 2007; Raab, Mayer, \& Shoemaker, 2010). An activity based costing model by Raab (2003) shown in Figure 3 depicts the depth and comprehensiveness of the method as it allocates costs from both front of house and back of house functions of the restaurant into each menu item.

On the other hand, Fang \& Hsu (2012), O’Donnell, Rao, \& Battese (2008), Reynolds \& Taylor (2011) and Taylor, Reynolds, \& Brown (2009) have attempted to apply data envelopment analysis to measure the efficiency of menu items within a restaurant. This method considers the efficiency of input variables (ingredients, labour and preparation) versus output variables (sales, profit margin, popularity and price). 


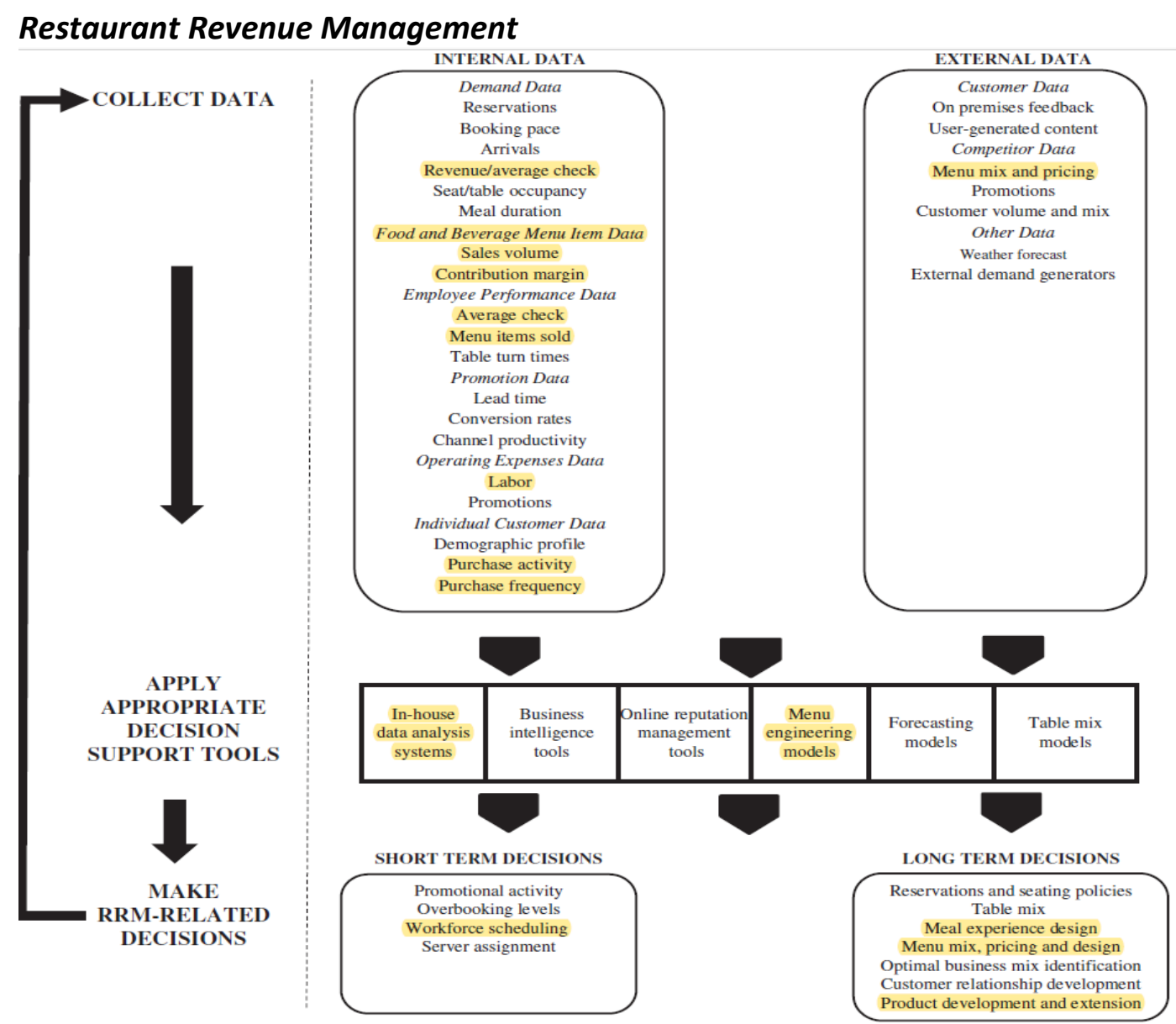

Figure 4 Restaurant revenue management decision framework (Noone \& Maier, 2015)

Another approach to menu management that focuses on optimizing restaurant operations and sales is revenue management. This concept was borrowed from the airline and hotel industry and there has been attempts to implement revenue management in restaurants to support better decision making and optimization of menu revenue (Kimes, Chase, Choi, Lee, \& Ngonzi, 1998). Practical examples of restaurant revenue management are to manage anticipated demand through set menus and happy hour promotions to optimize revenue at all operational hours. According to Heo (2013), restaurants are considered non-traditional revenue management businesses, and hence possess several limitations in implementing revenue management concepts. Referring to the restaurant revenue management decision framework proposed by Noone \& Maier (2015) in Figure 4, revenue management very much considers both internal and external data of the restaurant to develop effective decisions. While this is a proposed conceptual framework, it can be said that there is great potential to integrate menu analysis and revenue management functions together to perform better menu profitability management (Lai et al., 2019).

\section{Limitations and Applicability of Existing Methods}

Having identified that the key concepts of menu management consist of menu analysis and revenue management, researchers and practitioners who approach this topic from a practical perspective may express scepticism and limitations of applying such concepts within a practical setting. The successful application of menu analysis and revenue management techniques require consistent records of sales data, well defined strategy, knowledgeable and 
committed teamwork within a restaurant to execute successful menu analysis and revenue management techniques (Etemad-Sajadi, 2018; Kimes \& Beard, 2013; Raab \& Zemke, 2016). The above literature review presents the major concepts that are commonly practiced within menu management. While in theory it makes sense to allocate specific costs to menu items and implementing demand-based variable pricing, recent studies suggest that there are limitations to these approach that restrict the effective implementation in daily operations.

\section{Limitations of Menu Analysis Techniques}

According to Jones \& Mifli (2001), prior research work done on menu analysis were conceptual. A notable survey previously done by Morrison (1996) highlighted that menu decision makers shown no evidence of applying formal menu analysis methods in upscale Australian restaurants. The survey concluded that most respondents have good understanding in the costing of their menu items, but do not apply menu analysis tools within respective restaurants despite having theoretical knowledge in menu analysis. Essentially, most menu decision makers aim to focus on menu item quality and restaurant pride rather than short term profitability. Similarly, many respondents implied that associating labour costs and other operating costs were impractical due to the low profit multiplier effect. This notion was later supported by Taylor \& Brown (2007) as well, proving that there was little practical success in allocating specific restaurant costs to menu items. This finding was also consistent where Raab \& Zemke (2016) noted that independent restaurant managers were not familiar with the concept of activity based costing, and prefer to perform costing based on menu item contribution margin instead. That said, there is no significant research emphasizing the consistent application of menu analysis within independent restaurants.

\section{Limitations of Restaurant Revenue Management}

While revenue management techniques have previously been proven successful in the hotel and airline industry, restaurants face difficulties in implementing restaurant revenue management. A study done by Vieveen (2017) depicts that the business model of restaurants are more emotional, focusing on guest satisfaction to create return customers to maintain a stable revenue. Hotels and airlines on the other hand are more transactional, as the market perceives the hotel room and airline seat as a product. Henceforth, a personalized approach should be used to implement revenue management in restaurants. Not only that, Kimes \& Beard (2013) stressed that there pose to be many challenges in regard to implementation and integration of revenue management techniques within traditionally managed restaurant establishments. Varini, Burgess, \& Lane (2010) agreed that decision makers are facing challenges in identifying the new skills required to implement a revenue management program.

\section{Application of Existing Methods in SMEs}

As there were no significant literature highlighting the application of menu analysis and revenue management in SME restaurants, we can borrow findings from past studies that examine the challenges of SME restaurants. A study done by Kwong (2005) that applies menu engineering methods to SME restaurants concluded that menu decision makers primarily rely on qualitative judgements and experience to assume the popularity and profitability of their menu items whereby showing minor interests in applying menu analysis approaches. According to Salikin, Wahab, \& Muhammad (2014), SMEs in Malaysia commonly face the constraints of management skills and the success of businesses depend on the entrepreneur's 
experience. For this reason, intellectual capital was considered as the most crucial success factor for SME establishments (Khalique, Isa, Shaari, \& Ageel, 2011). At the same time, existing resources and assistance programs that guide SMEs in business management pose to be more theoretical than practical and hence resulted in the rise of SME failure rates (Chong, 2012). Due to the lack of management knowledge of most SME establishments in Malaysia, Ernst \& Young (2018) reported that decision makers face difficulties in managing costs and improving productivity. That said, Gunto \& Alias (2013) depicted that SMEs seldom focus on human resource training and development due to cost and time concerns. Henceforth, SME restaurants in Malaysia maybe incapable of implementing menu analysis and revenue management techniques effectively due to unavailability of proper infrastructure, knowledge, and tools.

In this paper, we explore measures taken by SME restaurant decision-makers in Kuala Lumpur to garner a better understanding of their chosen methods to menu management based on their operating business environment. Through this preliminary study, we set out to gain practical insights by identifying critical components of managing a menu in Kuala Lumpur.

\section{Methodology}

This exploratory study applied qualitative methods for data collection. Qualitative studies commonly support better understanding of contextual and complex organizational problems (Easterby-Smith, Thorpe, \& Lowe, 2002). Henceforth, a qualitative inquiry will provide more depth and understanding on the thought process in menu management of SME decision makers within this study. To depict findings from the point of view of SME decision makers, individual in-depth interviews were used as the primary method of data collection followed by observations and menu review. According to Alshenqeeti (2014), data collected through interviews reflect reality and yield more complete responses. Moreover, the intention of indepth interviews are to understand the "lived experience" of the participants without generalizing the findings (Charmaz, 1990). Open-ended interviews were conducted with SME F\&B business decision-makers representing a mix of SME F\&B outlets found in Kuala Lumpur. The open-ended questions were designed to understand how decision-makers develop, monitor, and modify their menu.

Key areas of inquiry were:

1. How is it like to operate a SME restaurant within Kuala Lumpur?

2. What are the measures taken to ensure profitability within their respective restaurants?

3. What are the key considerations when implementing a menu management strategy? As noted within the literature review, existing menu management methods were mostly developed based on theoretical implications. To explore this domain from a practical perspective, the first question provided researchers with a clearer understanding of the business environment for SME restaurant operators. This is followed by the second question, focusing on why decision makers do what they do according to their existing business environment. Through garnering a better understanding of the common practices done by practitioners, researchers can then conclude on the key concerns to focus on when developing practical menu management methods.

With that said, the key objectives of this study are as follows:

1. To understand the business environment of SME restaurants.

2. To explore actions performed by practitioners during unexpected circumstances. 
3. To identify the prime considerations in menu management from a practical perspective.

This study employed a purposive maximum variation sampling approach to compile the best practices of SME F\&B practitioners. The criteria for selecting SMEs was based on the specifications by SME Corp (2016), signifying that service-based businesses are those that operate with less than RM30 million per annum. Gathering insights from decision-makers of independent and multi-outlet SME's allowed this study to explore variabilities in managing menu profitability by company size. Data collected reached saturation at 10 participants when participants from shared similar inferences regarding their considerations when managing a profitable menu. As highlighted by Dworkin (2012), research studies are considered saturated when there are no new relevant data that contribute to the research question. The recruited participants consisted of four multi-outlet decision-makers and six independent outlet decision-makers. Six decision-makers owned their respective businesses and the remaining four were hired decision-makers. Participant identities were kept anonymous and given

\begin{tabular}{|l|l|l|l|}
\hline Pseudonym & $\begin{array}{l}\text { Decision } \\
\text { Position }\end{array}$ & $\begin{array}{l}\text { Type of SMEr' } \\
\text { Establishment }\end{array}$ & Business Size \\
\hline Ali & Manager & Independent & Small \\
\hline Bahran & Manager & Independent & Small \\
\hline Chong & Manager & Independent & Small \\
\hline Danny & Owner & Multi-outlet & Medium \\
\hline Eddy & Owner & Independent & Micro \\
\hline Firdaus & Owner & Multi-outlet & Medium \\
\hline Gopal & Owner & Independent & Small \\
\hline Hafiz & Owner & Multi-outlet & Medium \\
\hline Intan & Manager & Multi-outlet & Small \\
\hline Jaafar & Owner & Independent & Micro \\
\hline
\end{tabular}

pseudonyms for reporting purposes. Table 1 shows a summary of participant profiles.

Table 1 Study Participant Profiles

The average duration of the in-depth interviews conducted were 45 minutes each. Interviews were intentionally open-ended and unguided to discover new content or ideas that were seldom discussed in present literature within the domain of menu analysis and revenue management. Probing during the interviews allowed for better understanding on the topics brought up by respondents. An interview guide assisted in understanding participants' thought processes and challenges faced in menu management within their operating environments.

Data collected from the field was refined through template analysis. This method of analysis commonly defines priori themes to help ensure focus on the key areas of enquiry, supporting the development of existing theory (Brooks, McCluskey, Turley, \& King, 2015). Template analysis organizes the first few transcripts into a template, thereafter examining the remaining transcripts to interpret data (King, Brooks, \& Tabari, 2018). Interviews were first recorded and then transcribed. 68 pages of text data were generated through this process. NVIVO 12 qualitative data analysis software was used to organize and analyse the qualitative interview data. The transcripts were first reviewed to garner an understanding on the key activities performed pertaining to the research question. Initial codes were first developed from the first three transcripts to define a general template of ideas, and thereafter, subcategories were created subsequently upon analysing remaining transcripts. 
A total of 435 codes were first developed, and thereafter assigned into 29 categories followed by defining 4 key themes based on interrater reliability performed among the authors and then reviewed by co-researchers knowledgeable in restaurant management research. While authors achieved an $80 \%$ consensus among the preliminary codes developed in terms of relevancy, there was only $65 \%$ of agreement on the proposed categories because there was no coding guide given. This was intentional for the purpose of this exploratory study to identify uncommon findings. Based upon the consensus among the authors' subcategories, themes were then developed to devise a model emphasizing the key considerations of managing a menu for SME restaurants. Member checks were performed as necessary to acquire confirmation on findings. Similarly, triangulation was done to reaffirm participant's viewpoints through workplace observations of management workflow and menu reviews. For example, the main categories derived by authors were presented over the phone to interview participants to seek their further affirmation. Field notes and photos were taken within the workplace to provide supportive evidence throughout data analysis that allows the authors to have more context in understanding each participant's point of view while defining subcategories. This is relevant as the style of a restaurant's menu will normally dictate the style of décor and workplace management (Taylor \& Brown, 2007). Findings that contribute to the model was constantly compared against existing literature to identify differences and similarities showing potential gaps in menu management methods between researchers and practitioners.

\section{Findings and Results}

Through the categorization of codes, findings suggest that the actions performed during menu development and menu modification presented many similarities and hence was categorized together. On the other hand, when decision-makers were questioned on the method of monitoring their menu performance, findings show strong association with ideas supporting efficiency and maintaining consistency. In addition, the relevance of menu positioning and menu pricing emerged to be of importance when managing menu profitability. In this paper, the main reoccurring themes derived from the key activities will be discussed to understand what SME restaurant decision-makers do to stay afloat within Kuala Lumpur's competitive restaurant industry.

Out of all the interviewed participants, decision-makers who are also owners often did not come from the food and beverage industry. Hence, they operated their restaurants through hiring experts and consultants, possessing an open mind to implementing changes while learning from examples and best practices. On the other hand, hired managers who are decision-makers of the establishment were commonly experienced and knowledgeable. These managers had more examples to share from past work experiences as well as implementing those examples in their current role. Multi-outlet decision-makers have shown to be more organized as standards are set to ensure consistency across outlets. Independent restaurant decision-makers, however, have more flexibility in implementing changes having more ability to adapt quicker to changes in the business environment.

\section{Key Activities of Menu Management and Analysis}

This section will depict the measures taken by restaurateurs in Kuala Lumpur when managing and analysing their menus considering the internal and external conditions. Decision-makers pointed out that the service industry is very much different from the manufacturing industry. The service industry relies highly on the human touch while the manufacturing industry relies 
on the quality of machinery to operate efficiently. Hence, even when methods or even standard operating procedures (SOPs) are implemented, decision-makers face difficulties in achieving a profitable menu due to the unpredictable nature of human behaviours.

\section{Menu Development and Modification}

The main activity regularly undertaken by decision-makers was menu development and modification. Most decision-makers take considerable measures according to their capacity before confirming launching their menu items in order to mitigate major modifications to the menu in the future. An experienced manager decision maker emphasized that during the development phase, "there should be a reason to why each item is listed on the menu". This is to ensure that there are no redundant or costly items to be maintained on the menu. This view is commonly supported by menu analysis experts advocating that ineffective menu items should be removed or modified (Kasavana \& Smith, 1982; Miller, 1980; Pavesic, 1983). Similarly, many decision-makers shared that it is difficult to find a balance in providing quality food while achieving reasonable margins. Decisions were thus not made solely based on actual costs and figures as many decision-makers rely on a volume-based business to survive. Nevertheless, all participants agreed that providing quality food with affordable pricing is vital to keep customers coming back. Multi-outlet restaurant owner Hafiz mentioned that "It even makes the waiter's job easier in upselling quality menu items". This is because higher quality produce such as a steak's marbling grade will be stated on the menu and hence require less explanation in regards of justifying the price.

Restaurants normally have a fixed timeline for modifying their menus; multi outlet restaurants maintain the same menu for a longer period while independent restaurants have the option to modify their menu every 3 to 6 months. Although Bernstein, Ottenfeld, \& Witte (2008) suggested that customers often seek more variety in menu items, most of the decisionmakers in the current study said that their returning customers prefer consistency in menus. As a result, most only modify their menus when the entire menu is reprinted. This means that unprofitable items would still be kept on the menu despite low performance in sales. This helps to explain why decision-makers were more cautious in menu development and were confident that only minor modifications were needed to adjust the menu specifications.

Responses show that multi outlet restaurants have more limitations in modifying their menus because of the need to ensure uniformity in executing new menu items and removing unprofitable menu items across all outlets. On the other hand, independent restaurants have more flexibility and control in adapting to the changing environment. From this standpoint, independent restaurants have an upper hand in creating more attractive menus to compete with multi outlet restaurants. Moreover, independent restaurants can take better measures to sell off unpopular menu items by offering flash promotions at cost price before discarding unprofitable menu items. Independent restaurant owner Jaafar pointed out that he was able to tackle slow moving menu items by immediately coming up with set meal promotions for the subsequent days. Multi-outlet restaurant owner Danny had to take strict measures in implementing promotions as they had to assure uniformity in offerings across the different outlets to maintain customer expectations. Firdaus, also a multi-outlet restaurant owner depicts that the implementation of promotions in multi-outlet restaurants are more time consuming, requires more considerations and the cooperation of all outlets. The drawback of this is that multi-outlet restaurants report different sales performance for the same menu item because the outlets are serving different demographics. Hence, a promotion may only benefit certain outlets while hurting other outlets. 


\section{Product Market Fit}

Decision-makers share that there should be a focused concept when developing a menu. This concept should be consistent throughout the restaurant's style of service and ambience. Majority of the participants share that they aim to create returning customers, and hence prefer to offer variations of familiar dishes on altered menus for different meal periods. This is true according to Bernstein, Ottenfeld, \& Witte (2008) whereby customers often have higher perceived value there is more variety of menu items.

However, most SME decision-makers stay away from peculiar and uncommon menu items. In order to make sure that menu items are suited for the target market, decision-makers from multi-outlet businesses experiments with new menu items separately to test customer acceptance before introducing it into the main menu. Danny revealed that, "normally, every quarter we will add some new products and test the market. For example, this month we launched a nasi lemak series on a separate menu, and we collect feedback from customers and monitor performance for 3 months, then we decide whether we will add it to the new menu for the following year."

Multi-outlet restaurants often take more precaution when launching a new menu items as they need to ensure not to compromise on quality and efficiency when introducing new menu items across all outlets. On the other hand, independent restaurants were able to make spontaneous decisions offering items that are trending or in season at a good price. Jaafar highlighted that "For today, I decided to make a promotion on lamb chops, because yesterday I managed to buy in bulk lamb shoulders at a good price". While both independent and multioutlet restaurants try to constantly adjust their menus to attract and retain their customers, independent restaurants have the advantage in implementing more varied and attractive menu items within a shorter period.

An interesting finding was that several decision-makers supported the strategy of maintaining loss leaders within a menu. Loss leaders are menu items that generates volume but contribute low margins. Decision-makers have understood that they required loss leaders to attract returning customers into the restaurant and expects to compensate the profits by upselling other higher margin menu items. While this concept has been acknowledged by Ryan (1993) to help improve the performance of complementary menu items, it contradicts the assumptions of menu analysis methods (Cohen, Ghiselli, \& Schwartz, 2006).

\section{Access to Menu Ingredients}

Having consistent access to the ingredients required by the newly developed menu is key to ensuring operational efficiency. Independent restaurant decision-makers prefer to order more from the same supplier to save time but not necessarily costs. On the other hand, multioutlet restaurants would keep at least two suppliers for critical and fast-moving ingredients to ensure constant availability and best value. A major challenge in this area is the frequent price fluctuation of fresh produce making the role of menu costing difficult. This resulted in decision-makers having to order more frozen produce to reduce wastage. Decision-makers should however, factor in the volatility of costs to ensure that enough margin is enough for the restaurant to be profitable. Nevertheless, decision-makers suggested that it is important to maintain good supplier relationships so that restaurants negotiate better credit payment terms and receive updated information. 


\section{Menu Positioning, Marketing, and Presentation}

Decision-makers suggestively agree that when menu items are developed or modified, follow up is needed to properly position, market and present the menu to showcase the concept or theme that the restaurant is focusing on. It supports in getting the right customer into the restaurant. In any case, the language and description of the menu should be easily understood by customers. Previous studies shown that detailed and well-presented menus were able to increase the perceived value (Iglesias \& Guillén, 2004; Shoemaker, Dawson, \& Johnson, 2005). Not only that, decision-makers emphasized that menu items with pictures perform better than menu items without pictures. This is true as studies have shown that better description, design and visuals of the menu significantly increases the likelihood of consumption (Guéguen, Jacob, \& Ardiccioni, 2012; Reynolds, Merritt, \& Pinckney, 2005).

\section{Workplace Pride}

Through compiling opinions from respondents, positioning of the menu also affects employee perception. Multi-outlet decision-makers supported that a well-positioned menu creates pride and loyalty for the workplace which reduces employee turnover. An establishment with a signature dish or focused menu will help qualify the most suitable employees for the restaurant. Hafiz added that,

"people prefer to work for Japanese restaurants. they won't work for local restaurant as they perceive it as a lower-class establishment. This is evident through looking at the average check, a Japanese restaurant makes per person 30, 40, 50 ringgits per person while in Old Town (famous local chain all day restaurant) they make 10, 15 ringgits per person".

The local restaurant industry workforce is more demanding in choosing their workplace as they seek for more reputable establishments to portray a higher status among their peers. This resulted in local restaurant owners having to seek help from family members and hire foreign workers to cover shortage of labour.

\section{Menu Operational Efficiency, Effectiveness, and Consistency}

All decision-makers possess various backgrounds, skills and capabilities which essentially translates into the management style of the entire restaurant. Nevertheless, in order to maintain efficiency, effectiveness and consistency, decision-makers agree that having standard operating procedures (SOP) are essential. This is where all decision-makers look to franchise and chain restaurants for reference in developing SOPs. Often, multi-outlet businesses have already an organized workflow are well aware of their costs. Multi-outlet businesses take longer time to change SOPs and are less adaptable to unexpected circumstances compared to independent businesses.

\section{SOPs Developed based on Employee Capability and Attitude}

According to Namkung \& Jang, (2010) service failures especially during the meal consumption phase, will result in the depreciation of customer satisfaction discouraging returning customers. Every employee possesses various backgrounds, skills and capabilities. Therefore, it is important for decision-makers to allocate responsibilities according to the skills and capability of every employee. Participants suggest that knowledgeable and capable employees were able to drive more menu sales. Not only that, decision-makers must adapt their management style in consideration of the existing employees. Because as we realized, employees in Kuala Lumpur were very multicultural, and hence have different workstyles and cultures. A younger aged decision maker expressed that sometimes there were difficulties in 
managing and giving orders to older aged employees. Furthermore, many participants found that it was challenging to get the team to move the same direction and look at the same goal. With that in mind, decision-makers would look to implementing strict SOPs. However, findings show that the success of executing SOPs were also dependent on the capabilities and skills of employees. Therefore, SOPs should always be developed according to both the requirements of the menu item with the restaurant and employee's capability in mind. For example, the number of available cooks must be able to cope with the forecasted demand for a meal period. All these challenges may result in occasional operational breakdown and eventually weakens the performance of menu items.

\section{Menu Performance Tracking}

The point of sale (POS) system is an essential tool for the restaurant industry. While all decision-makers agree that full utilization of the POS will help in better decision making, many participants admit that they do not have the time to key in specific cost data into the POS system especially for smaller sized restaurants. Nevertheless, it should be noted that decisionmakers should not rely only on POS data as more justification is needed to help describe what reflected the sales performance. Usage of the POS data with qualitative data from employees and considerations such as past public holidays, weather conditions and events will provide better insights for future decision making.

\section{Menu Pricing and Costing}

The most intricate part of managing a menu is deciding on the pricing and costing of the intended menu items. Decision-makers reveal that their pricing and costing of menu items are often done concurrently, whereby they set prices based on market trends and affordability and then adjusts costing to allow for enough margin. Due to the lack of resources, a very innovative practice done by one of the independent decision-makers who has a F\&B background shared that they set pricing based on established restaurants of similar concept, because they believe that established restaurants have properly accounted costs. Another participant who operates multi-outlet restaurants had instead set menu prices and costs based on a targeted profit margin for every menu item. This means that they can maintain fair pricing while providing adequate level of service and quality of food. A simpler method done by independent restaurants were to calculate total sales and total costs for a certain period to determine performance of the menu. Once the parameters for menu pricing and costing were determined, decision-makers would then operate and adjust menu specifications as needed depending on staff capability, ingredient seasonality, upcoming events or holidays and trending news.

\section{Time is Money}

While Vaughn, Raab, \& Nelson's (2010) view of applying activity based costing to support kitchen operations seemed feasible, it may be impractical to be implemented by practitioners in Kuala Lumpur. Decision-makers expressed that it was impractical to account for all costs into the pricing of menu items. Nevertheless, it is important to have good understanding of the potential costs associated to producing the developed menu items. Looking from a practical perspective, it was instead more important to be able to control and adjust costs accordingly adapting to the business and operational environment. For example, decisionmakers must take measures to decide on purchasing more expensive pre-made ingredients to save time or cheaper raw ingredients which would incur time costs for preparation. 
Similarly, decision maker faces the dilemma of managing inexperienced employees whereby their capabilities impact efficiency. Incapable employees would take longer time to prepare and serve food reducing the revenue generated per hour while increasing the labour cost of operating a menu. This phenomenon is fairly common as past studies suggested implementing data envelopment analysis to measure the efficiency of labour in regard to sales (Fang \& Hsu, 2012). However, the complications and knowledge required to apply such methods makes it impossible for practitioners to implement without a dedicated analyst. A common practice done by multi-outlet decision-makers are to account for part-time and fulltime labour costs, incurred fixed and variable costs daily. This is in order to better understand the performance of employees as well as popularity of menu items depending on the day of week.

\section{Pricing Acceptance and Value Perception Fit}

A past study by Heo et al. (2013) show that a change in menu pricing influence customer value perception while scarcity in restaurant capacity do not affect any perceived value. Similarly, participants in this study agreed that it is important to consider the value perception of the target market when determining pricing. Higher quality items sold at higher prices may not seem affordable, while low quality items at sold cheap prices may not be appealing. Interestingly, certain low margin items that are expected of the customers cannot be charged high prices despite high demand, and menu items that have low cost may have high price perception from the consumers view. Hafiz, a multi-outlet restaurant owner decision maker made a strong point sharing that "You see even sometimes I can sell spaghetti, which costs less than curry noodles to produce. Curry noodles has more ingredients, actually takes longer time to cook incurring more food and labour costs, but people expect curry noodles cannot be that expensive. But spaghetti, customers say that its western food, hence they are more willing to pay more" Customers in certain market or locations may not appreciate the quality of food, hence there may be a potential opportunity to reduce costs on certain ingredients. Finally, it was also recommended to predefine costing guidelines to ensure that the developed menu items can be maintained within a focused price range to retain positioning among the target demographic. Intan, an experienced restaurant manager stressed that "Certain places you see have really cheap prices for menu items, but when it comes to salmon or unagi dishes, its super high price, because they tell you its fresh from Norway or Japan, so there's a huge price gap. These menu items do not make sense on a fast-casual restaurant." The huge price gap across menu items will create confusion for diners and more wastage in kitchen operations as excessively priced items are often slow moving. Decision makers must find a balance between quality and price that suit their target demographic. Having persistence in justifying the menu pricing through providing exceptional value is vital to create loyal customers. As all participants agree, loyal customers are less price sensitive and they never aim to win customers through offering cheap prices.

\section{Higher Margins Provide more Flexibility}

Margins allow a business to survive, and hence decision-makers often try to ensure that the profit margins for menu items are enough for growing the business. Multi-outlet decisionmakers make a very good point in emphasizing the need to allocate enough margins when setting the prices of menu items to overcome unforeseen circumstances. This was to prevent the sudden need to raise prices on the menu or suffer thin margins when unfortunate events occur. As suggested by researchers as well, there will be a need to implement a cost control 
system and set aside budgets to cover unexpected costs (Borchgrevink \& Anchill, 2008; T. A. Jones, 2008). To do this, constant monitoring of direct competitor prices will provide greater insight to how much extra that a restaurant can charge. The allotted margins after all cost of goods sold should cover all expenses and not limited to overhead, maintenance, research and development, insurance as well as professional fees depending on the business environment of the restaurant.

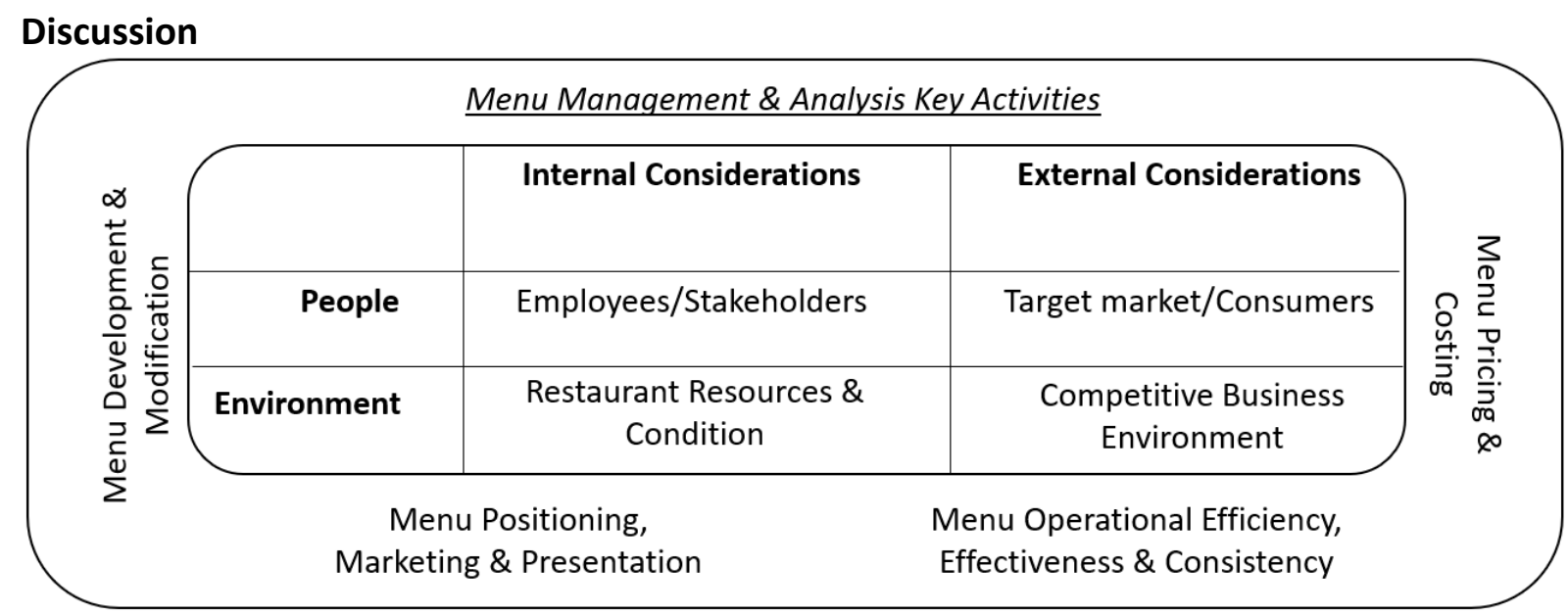

Figure 5 Menu Management Model

Referring to Figure 5, findings show that decision-makers in Kuala Lumpur manage and analyse menus through constantly performing four key activities, (1) menu development and modification; (2) menu positioning, marketing, and presentation; (3) menu operational efficiency, effectiveness, and consistency; (4) menu pricing and costing. The main themes that emerged among the four key activities emphasized the importance of considering the people and environmental conditions both internally and externally when performing all key activities of menu management and analysis. This is to say that decision-makers must be flexible in adapting to ever changing and unpredictable situations that surface from both the people and business environment where the restaurant is operating. Employees and stakeholders refer to all associated team members that operates the menu and restaurant. Restaurant resources and condition considers all existing equipment, resources, and capability in executing the menu. The target market and consumers are the diners who consume the menu, providing the main source of revenue sustaining the restaurant. Finally, the competitive business environment is the uncontrollable surrounding where the menu and restaurant is operated in.

\section{Conclusion}

This paper attempted to gather insights from practitioners about practices in menu management collectively combining the key activities of menu management and analysis. Findings show that, practitioners do not actually follow any method, but they practice, mix and match suitable methods to be applied based on their background, knowledge and experience considering the internal and external factors as well.

A review of approaches and methods presented indicates that existing methods of menu analysis have been mostly quantitative based whereby more qualitative methods are needed to support better decision making (Mifli, 2001; Taylor \& Brown, 2007). As agreed by Ozdemir \& Caliskan (2014), it is important to establish a balanced strategy through understanding the 
external environment and internal functions of a restaurant. Through this study, findings were able to show that practitioners do operate their menus with heavy considerations of the business environment, but only lack the knowledge to conduct effective menu analysis.

Another key finding from this study was that sourcing for good human resources posed to be challenging because employee loyalty is hard to maintain especially when SMEs do not have an established brand or presence in the market. Decision-makers struggle to train and keep employees for a long term and resulted in hiring foreign unskilled labours. Multi-outlet decision-makers posed to be more organized and strategic while independent decisionmakers showed great capability to be adaptive and resourceful to maintain operational efficiency despite not consistently implementing SOPs. Finally, allocating the right amount of margin for menu items seemed to be vital to overcome unexpected circumstances within the business environment. At the same time, managing a good balance of price and consumer perception will create return customers.

On the other hand, it is noticed that decision-makers were not very familiar with the concept of revenue management. Although decision-makers try their best to optimize revenues through organizing events, providing external catering, and upselling menu items, however, these mentions were not impactfully executed with strategy. Similarly, in line with Ryu, Jang, \& Sanchez (2004), the notion of forecasting for demand was still foreign to practitioners in Kuala Lumpur. This may result in more wastage and the challenge of justifying the need to hire more employees.

\section{Limitations and Future Research}

This preliminary study poses several limitations as it highlights only menu management functions within SME restaurants in Kuala Lumpur. The findings suggested are not to generalize and are limited based on participant's views. Propositions of this paper are to explore the challenges faced by practitioners to support the development of menu management methods for independent SME restaurants.

As highlighted by Etemad-Sajadi (2018) and Raab \& Zemke (2016), the sophisticated methods of menu analysis and revenue management posed to be relatively impractical to be implemented in restaurants on a day to day basis. Hence through this exploratory study, further research can be done to probe in depth on each of the key considerations of menu management. This can support the development of a practicality assessment model that helps decision-makers to gauge the conditions of their restaurant to determine the most suitable menu management and analysis considerations.

Furthermore, Ozdemir \& Caliskan (2014) emphasized that there is a need to study the domain of menu management as a whole comprising planning, pricing, designing, operating and analysis of menus. Taking note of Noone \& Maier's (2015) restaurant revenue management decision framework, a solution that encompasses all critical components and key considerations for menu management and analysis can be developed to provide guidance for SME restaurant practitioners particularly in Kuala Lumpur. This can be in the form of a comprehensive menu profitability management framework developed through combining both menu analysis and revenue management concepts incorporating qualitative and quantitative data.

\section{Theoretical and Contextual Contribution}

Based on the findings from this study, menu analysis and revenue management concepts are concurrently implemented and selectively applied in SME restaurants when viewed from a 
practical perspective. This shows that MA and RM methods within existing literature are not fully implemented on a practical capacity. This is because SME restaurants often have limited resources and capabilities resulting in making reactive decisions rather than devising preventive strategies.

This study found that when using MA and RM to make menu management decisions in SME restaurants, considering the people and business environment factors would help produce actionable decisions with sound justifications.

As there is no one size fits all approach, menu management decisions and strategies are often devised based on existing capabilities and experience of the decision makers. Employing a mix of qualitative and quantitative methodology are essential for making better judgment on the viability of a strategy.

The developed menu management model depicted in figure 5 presents the potential domains of consideration when making menu management related decisions. This is especially useful for small scale establishments with limited resources. Keeping these considerations in mind will yield more pragmatic and accountable decisions.

\section{References}

Alshenqeeti, H. (2014). Interviewing as a Data Collection Method: A Critical Review. English Linguistics Research, 3(1), 39-45. https://doi.org/10.5430/elr.v3n1p39

Antun, J. M., \& Gustafson, C. M. (2005). Menu Analysis : Design, Merchandising, and Pricing Strategies Used by Successful Restaurants and Private Clubs. Journal of Nutrition in Recipe \& Menu Development. https://doi.org/10.1300/J071v03n03_07

Bayou, M. E., \& Bennett, L. B. (1992). Profitability Analysis for Table-Service Restaurants. Cornell Hotel and Restaurant Administration Quarterly, 33(2), 49-55. https://doi.org/10.1177/001088049203300220

Bernstein, D., Ottenfeld, M., \& Witte, C. L. (2008). A study of consumer attitudes regarding variability of menu offerings in the context of an upscale seafood restaurant. Journal of Foodservice Business Research. https://doi.org/10.1080/15378020802519769

Borchgrevink, C., \& Anchill, D. (2008). Beverage Control Systems and the Guests' Perspective: Standardization and Value. Journal of Hospitality \& Leisure Marketing, 10(1), 151-159. https://doi.org/10.1300/J150v10n01_10

Brooks, J., McCluskey, S., Turley, E., \& King, N. (2015). The Utility of Template Analysis in Qualitative Psychology Research. Qualitative Research in Psychology, 12(2), 202-222. https://doi.org/10.1080/14780887.2014.955224

Charmaz, K. (1990). "Discovering" chronic illness: Using grounded theory. Social Science and Medicine, 30, 1161-1172.

Chong, W. Y. (2012). Critical Success Factors for Small and Medium Enterprises: Perceptions of Entrepreneurs in Urban Malaysia. Journal of Business and Policy Research, 7(4), 204215.

Cohen, E., Ghiselli, R., \& Schwartz, Z. (2006). The Effect of Loss leader Pricing on Restaurant Menus' Product Portfolio Analysis. Journal of Foodservice Business Research, 9(1), 2138.

Cohen, E., Mesika, \& Schwartz, Z. (1998). A multidimensional approach to menu sales mix analysis. Praxis, 1(1), 130-144.

Dalci, I., Tanis, V., \& Kosan, L. (2010). Customer profitability analysis with time-driven activitybased costing: A case study in a hotel. International Journal of Contemporary Hospitality Management, 22(5), 609-637. https://doi.org/10.1108/09596111011053774 
Dworkin, S. L. (2012). Sample Size Policy for Qualitative Studies Using In-Depth Interviews. Archive of Sex Behaviors, 41, 1319-1320. https://doi.org/10.1007/s10508-012-0016-6

Easterby-Smith, M., Thorpe, R., \& Lowe, A. (2002). Management Reserch: An Introduction (2nd ed.). London: SAGE Publications.

Ernst \& Young. (2018). ASEAN SMEs Are you transforming for the future? Retrieved from https://www.ey.com/Publication/vwLUAssets/ey-asean-smes-are-you-transformingfor-the-future/\$FILE/ey-asean-smes-are-you-transforming-for-the-future.pdf

Etemad-Sajadi, R. (2018). Are customers ready to accept revenue management practices in the restaurant industry? International Journal of Quality and Reliability Management, 35(4), 846-856. https://doi.org/10.1108/IJQRM-01-2017-0007

Fang, C. Y., \& Hsu, F.-S. (2012). An Efficiency-Based Metafrontier Approach To Menu Analysis. Journal of Hospitality and Tourism Research, 38(2), 199-221. https://doi.org/10.1177/1096348012451461

Glanz, K., Resnicow, K., Seymour, J., Hoy, K., Stewart, H., Lyons, M., \& Goldberg, J. (2007). How Major Restaurant Chains Plan Their Menus. The Role of Profit, Demand, and Health. American Journal of Preventive Medicine, 32(5), 383-388. https://doi.org/10.1016/j.amepre.2007.01.003

Guéguen, N., Jacob, C., \& Ardiccioni, R. (2012). Effect of watermarks as visual cues for guiding consumer choice: An experiment with restaurant menus. International Journal of Hospitality Management, 31(2), 617-619. https://doi.org/10.1016/j.ijhm.2011.04.008

Gunto, M., \& Alias, M. H. (2013). SMEs Developent in Malaysia: Lessons For Libya. In Persidangan Kebangsaan Ekonomi Malaysia ke VIII (pp. 1521-1530). Johor Bahru.

Hayes, D., \& Huffman, L. (1985). Menu Analysis: A Better Way. Cornell Hospitality Quarterly, 25(4), 64-70.

Heo, C. Y. (2013). Restaurant Revenue Management. In: Revenue Management for hospitality and tourism. (P. Legohérel, E. Poutier, \& A. Fyall, Eds.). Woodeaton: Goodfellow Publishers.

Heo, C. Y., Lee, S., Mattila, A., \& Hu, C. (2013). Restaurant revenue management: Do perceived capacity scarcity and price differences matter? International Journal of Hospitality Management, 35, 316-326. https://doi.org/10.1016/j.ijhm.2013.05.007

Iglesias, M. P., \& Guillén, M. J. Y. (2004). Perceived quality and price: their impact on the satisfaction of restaurant customers. International Journal of Contemporary Hospitality Management. https://doi.org/10.1108/09596110410550824

Jones, P., \& Mifli, M. (2001). Menu development and analysis in UK restaurant chains. Source: Tourism and Hospitality Research. https://doi.org/10.1177/146735840100300105

Jones, T. A. (2008). Improving hotel budgetary practice-A positive theory model. International Journal of Hospitality Management. https://doi.org/10.1016/j.ijhm.2007.07.027

Kaplan, R. S., \& Anderson, S. R. (2007). Time-driven activity-based costing: a simpler and more powerful path to higher profits. European Accounting Review, 16(4), 855-866. https://doi.org/10.1080/09638180701814171

Kasavana, M., \& Smith, D. (1982). Menu Engineering: A Practical Guide to Menu Analysis. Lansing: Hospitality Publications.

Kelly, T. J., Kiefer, N. M., \& Burdett, K. (1994). A Demand-Based Approach to Menu Pricing. Cornell Hospitality Quarterly. https://doi.org/10.1177/1938965509339038

Khalique, M., Isa, A. H., Shaari, J. A. N., \& Ageel, A. (2011). Challenges Faced by the Small and Medium Enterprises (SMEs) In Malaysia: An Intellectual Capital Perspective. International Journal of Current Research, 3(6), 398-401. 
Kimes, S. E. (2010). Strategic pricing through revenue management. Sage, 502-513. Retrieved from http://scholarship.sha.cornell.edu/articles/346

Kimes, S. E., \& Beard, J. (2013). The future of restaurant revenue management. Journal of Revenue and Pricing Management. https://doi.org/10.1057/rpm.2013.22

Kimes, S. E., Chase, R. B., Choi, S., Lee, P. Y., \& Ngonzi, E. N. (1998). Restaurant Revenue Management. Cornell Hotel and Restaurant Administration Quarterly, 39(3), 32-39. https://doi.org/10.1177/001088049803900308

Kincaid, C. S., \& Corsun, D. L. (2003). Are consultants blowing smoke? An empirical test of the impact of menu layout on item sales. International Journal of Contemporary Hospitality Management. https://doi.org/10.1108/09596110310475685

King, N., Brooks, J., \& Tabari, S. (2018). Template Analysis in Business and Management Research. In D. Jemmielniak \& M. Ciesielska (Eds.), Qualitative Methodologies in Organization Studies (2nd ed., pp. 179-206). Palgrave Macmillan.

Kwong, L. Y. L. (2005). The Application of Menu Engineering and Design in Asian restaurants. International Journal of Hospitality Management, 24, 91-106. https://doi.org/10.1016/j.ijhm.2004.05.002

Lai, H. B. J., Karim, S., Krauss, S. E., \& Ishak, F. A. C. (2019). Can restaurant revenue management work with menu analysis? Journal of Revenue and Pricing Management, 18(3), 204-212. https://doi.org/10.1057/s41272-019-00194-6

LeBruto, S. M., Quain, W. J., \& Ashley, R. A. (1995). Menu engineering: a model including labor. Hospitality Review, 13(1), 5. Retrieved from http://digitalcommons.fiu.edu/cgi/viewcontent.cgi?article=1237\&context=hospitalityre view

Mifli, M. (2001). Menu development and analysis, 3(1), 61-71.

Miller, J. E. (1980). Menu pricing \& strategy. Boston: CBI Publishing.

Morrison, P. (1996). Menu Engineering in Upscale Restaurants. International Journal of Contemporary Hospitality Management, 8(4), 17-24. https://doi.org/http://dx.doi.org/10.1108/09596119610119949

Morrison, P. (1997). Menu engineering in upscale restaurants. British Food Journal. https://doi.org/10.1108/00070709710195194

Naipaul, S., \& Parsa, H. G. (2001). Menu price endings that communicate value and quality. Cornell Hotel and Restaurant Administration Quarterly. https://doi.org/10.1177/0010880401421003

Namkung, young, \& Jang, S. (2010). Service Failures in Restaurants: Which Stage of Service Failure Is the Most Critical? Cornell Hospitality Quarterly. https://doi.org/10.1177/1938965510364488

Noone, B. M., \& Maier, T. A. (2015). A decision framework for restaurant revenue management. Journal of Revenue and Pricing Management, 14(4), 231-244. https://doi.org/10.1057/rpm.2015.15

O'Donnell, C., Rao, D., \& Battese, G. (2008). Metafrontier Frameworks for the Study of FirmLevel Efficiencies. Empirical Economics, 34(2), 1-34.

Ojugo, C., \& Rymer, T. (2009). Menu Analysis and Planning for Sales. In Practical Food and Beverage Cost Control (2nd ed., pp. 260-277). Cengage Leaarning.

Osterwalder, A., \& Pigneur, Y. (2010). Business Model Generation: A Handbook for Visionaries, Game Changers, and Challangers. Booksgooglecom.

Ozdemir, B., \& Caliskan, O. (2014). A review of literature on restaurant menus: Specifying the managerial issues. International Journal of Gastronomy and Food Science, 2(1), 3-13. 
https://doi.org/10.1016/j.ijgfs.2013.12.001

Pavesic, D. V. (1983). Cost/margin analysis: a third approach to menu pricing and design. International Journal of Hospitality Management, 2(3), 127-134. https://doi.org/10.1016/0278-4319(83)90033-6

Raab, C. (2003). The Feasability OF Activity-Based Costing In The Restaurant Industry. Itinerario. Course of Hotel Administration, Department of William f. Harrah College of Hotel Administration, University of Nevada, Nevada: Doctoral Dissertation. Retrieved from http://journals.cambridge.org/abstract_S0165115300023299

Raab, C., \& Mayer, K. (2007). Menu engineering and activity-based costing - Can they work together in a restaurant? International Journal of Contemporary Hospitality Management, 19(1), 43-52. https://doi.org/10.1108/09596110710724152

Raab, C., Mayer, K., Kim, Y. S., \& Shoemaker, S. (2009). Price-sensitivity measurement: A tool for restaurant menu pricing. Journal of Hospitality and Tourism Research. https://doi.org/10.1177/1096348008329659

Raab, C., Mayer, K., \& Shoemaker, S. (2010). Menu engineering using activity-based costing: An exploratory study using a profit factor comparison approach. Journal of Hospitality and Tourism Research, 34(2), 204-224. https://doi.org/10.1177/1096348009349823

Raab, C., \& Zemke, D. M. (2016). Activity-based costing in the restaurant industry: What's past is prologue. Journal of Hospitality Financial Management, 24(2), 133-146. https://doi.org/10.1080/10913211.2016.1239488

Reynolds, D., Merritt, E. A., \& Pinckney, S. (2005). Understanding Menu Psychology : An Empirical Investigation of Menu Design and Customer Response. International Journal of Hospitality \& Tourism Administration. https://doi.org/10.1300/J149v06n01

Reynolds, D., \& Taylor, J. (2011). Validating a DEA-based menu analysis model using structural equation modeling. International Journal of Hospitality Management, 30(3), 584-587. https://doi.org/10.1016/j.ijhm.2010.11.001

Ryan, N. R. (1993). R \& I Menus for The'90s: Balancing the Menu. Restaurants and Institutions, 103(6), 24.

Ryu, K., Jang, S. S., \& Sanchez, A. (2004). Forecasting Methods and Seasonal Adjustment for a University Foodservice Operation. Journal of Foodservice Business Research, 6(2), 17-34. https://doi.org/10.1300/j369v06n02_03

Salikin, N., Wahab, N., \& Muhammad, I. (2014). Strengths and Weaknesses among Malaysian SMEs: Financial Management Perspectives. Procedia - Social and Behavioral Sciences, 129, 334-340. https://doi.org/10.1016/j.sbspro.2014.03.685

Shoemaker, S., Dawson, M., \& Johnson, W. (2005). How to increase menu prices without alienating your customers. International Journal of Contemporary Hospitality Management. https://doi.org/10.1108/09596110510620636

SME Corp. (2016). Guideline For New SME Definition. Retrieved from http://www.smecorp.gov.my/images/pdf/Guideline_New_SME_Definition_updated.pd $f$

Taylor, J. J., \& Brown, D. M. (2007). Menu analysis: A review of techniques and approaches. Hospitality Review, 25(1985), 6. Retrieved from http://digitalcommons.fiu.edu/hospitalityreview/vol25/iss2/6/\%5Cnhttp://digitalcom mons.fiu.edu/cgi/viewcontent.cgi?article $=1453 \&$ context=hospitalityreview

Taylor, J., Reynolds, D., \& Brown, D. M. (2009). Multi-factor menu analysis using data envelopment analysis. International Journal of Contemporary Hospitality Management, 21(2), 213-225. https://doi.org/10.1108/09596110910935705 
Varini, K., Burgess, C., \& Lane, G. (2010). Maximising profits : Do revenue managers have the skills ?, 4(2).

Vaughn, P., Raab, C., \& Nelson, K. B. (2010). The application of activity-based costing to a support kitchen in a Las Vegas casino. International Journal of Contemporary Hospitality Management. https://doi.org/10.1108/09596111011066662

Vieveen, I. (2017). Lost Opportunities in Restaurant Revenue Management. Journal of Revenue and Pricing Management. https://doi.org/10.1057/s41272-017-0109-x 